\title{
Body size in relation to incidence of subtypes of haematological malignancy in the prospective Million Women Study
}

\author{
F Murphy ${ }^{1}, \mathrm{M}$ E Kroll ${ }^{*}{ }^{1}, \mathrm{~K}$ Pirie $^{1}, \mathrm{G}$ Reeves ${ }^{1}, \mathrm{~J} \mathrm{Green}^{1}$ and $\mathrm{V}$ Beral ${ }^{1}$ on behalf of the Million Women Study \\ Collaborators \\ ${ }^{1}$ Cancer Epidemiology Unit, Nuffield Department of Medicine, University of Oxford, Richard Doll Building, Roosevelt Drive, \\ Oxford OX3 7LF, UK
}

Background: Greater adiposity and height have been associated with increased risk of haematological malignancies. Associations for disease subtypes are uncertain.

Methods: A cohort of 1.3 million middle-aged UK women was recruited in 1996-2001 and followed for 10 years on average. Potential risk factors were assessed by questionnaire. Death, emigration, and incident cancer were ascertained by linkage to national registers. Adjusted relative risks were estimated by Cox regression.

Results: During follow-up, 9162 participants were diagnosed with lymphatic or haematopoietic cancers. Each $10 \mathrm{~kg} \mathrm{~m}^{-2}$ increase in body mass index was associated with relative risk of 1.20 (95\% confidence interval: 1.13-1.28) for lymphoid and 1.37 (1.22-1.53) for myeloid malignancy $(P=0.06$ for heterogeneity); similarly, Hodgkin lymphoma 1.64 (1.21-2.21), diffuse large B-cell lymphoma 1.36 (1.17-1.58), plasma cell neoplasms 1.21 (1.06-1.39), acute myeloid leukaemia 1.47 (1.19-1.81), and myeloproliferative/myelodysplastic syndromes 1.32 (1.15-1.52). Each $10 \mathrm{~cm}$ increase in height was associated with relative risk of 1.21 (1.16-1.27) for lymphoid and 1.11 (1.02-1.21) for myeloid malignancy ( $P=0.07$ for heterogeneity); similarly, mature T-cell malignancies 1.36 (1.03-1.79), diffuse large B-cell lymphoma 1.28 (1.14-1.43), follicular lymphoma 1.28 (1.13-1.44), plasma cell neoplasms 1.12 (1.01-1.24), chronic lymphocytic leukaemia/ small lymphocytic lymphoma 1.23 (1.08-1.40), and acute myeloid leukaemia 1.22 (1.04-1.42). There was no significant heterogeneity between subtypes.

Conclusion: In middle-aged women, greater body mass index and height were associated with modestly increased risks of many subtypes of haematological malignancy.

Although previous studies have reported associations of haematological cancer with adiposity (Renehan et al, 2008) and height (Gunnell et al, 2001; Engeland et al, 2007; Green et al, 2011), associations with specific disease subtypes are not yet wellestablished. Traditionally, epidemiological studies have used broad categories defined mainly by clinical features: Hodgkin lymphoma, non-Hodgkin lymphoma (NHL), leukaemia, and multiple myeloma. A new classification, introduced by the World Health Organisation (WHO) in 2001, divides haematological malignancies into lymphoid and myeloid neoplasms, and then more specifically according to cell lineage, so that each disease entity is defined by morphological, immunophenotypic, and genetic features (IARC, 2008). In this report, we describe associations of adiposity and height with risks of subtypes of haematological malignancy in women, using both traditional and updated disease classifications.

\section{MATERIALS AND METHODS}

Between 1996 and 2001, 1.3 million middle-aged women were recruited to the Million Women Study through the United

*Correspondence: Dr ME Kroll; E-mail: mary.kroll@ceu.ox.ac.uk

Received 18 December 2012; revised 18 March 2013; accepted 20 March 2013; published online 2 May 2013

(c) 2013 Cancer Research UK. All rights reserved 0007-0920/13 
Kingdom national breast cancer screening programme. Ethics approval for the study was given by the Multi-Centre Research Ethics Committee for Anglia and Oxford, and all participants provided written consent. Details of the study design have been published elsewhere (Reeves et al, 2007). Briefly, participants completed a questionnaire regarding personal, lifestyle, and health factors (www.millionwomenstudy.org), and are followed up for cancer diagnosis, emigration, and death, by linkage to National Health Service Central Registers. Each cancer registration is coded according to the International Classification of Disease 10th revision (ICD-10), with a morphology code from either the 2nd (ICD-O-2) or the 3rd edition (ICD-O-3) of the International Classification of Diseases for Oncology; for this study, ICD-O-2 morphology codes were converted to ICD-O-3 (SEER, 2001). All participants were asked to report their current height and weight at recruitment. In addition, a sample of study participants who responded to a study questionnaire during 2006-2007 were asked in 2006-2009 to have their height and weight measured by their family doctor (Armstrong et al, 2011; Green et al, 2011).

Registrations with the following ICD-10 topography codes were examined: C81-96 (malignant neoplasms of lymphoid, haematopoietic, and related tissue), D45 (polycythaemia vera), D46 (myelodysplastic syndromes), and D47 (other neoplasms of uncertain or unknown behaviour of lymphoid, haematopoietic, and related tissue). Those with ICD-O-3 code in the range M-959 to M-998 and behaviour code 3 were eligible for the study. Histiocytic and dendritic neoplasms (M-975) were excluded.

Haematological cancer diagnoses were classified in two ways. First, to allow comparison with older studies, we used broad disease categories based on ICD-10: Hodgkin lymphoma (C81), NHL (C82-85, C96), leukaemia (C91-95), and 'myeloma' (multiple myeloma and (other) malignant plasma cell neoplasms (C90) combined with malignant immunoproliferative diseases (C88)) (Ferlay et al, 2010). Secondly, we used a hierarchical classification adapted from the InterLymph and HAEMACARE projects, based on ICD-O-3 (Table 1) (Sant et al, 2010; Turner et al, 2010).
Lymphoid subtypes include plasma cell neoplasms (predominantly multiple myeloma), and chronic lymphocytic leukaemia/small lymphocytic lymphoma (CLL/SLL, combining subgroups of ICD10 categories 'leukaemia' and 'NHL' that are now considered to be the same disease). Myeloid cases are grouped as acute myeloid leukaemia and myeloproliferative/myelodysplastic neoplasms (myeloproliferative neoplasms and myelodysplastic syndromes, including chronic myeloid leukaemia); case numbers were insufficient for further subdivision. Details of the correspondence between the two classifications for haematological neoplasms in this cohort are reported elsewhere (Kroll et al, 2012).

Adiposity was assessed using body mass index (weight in kilograms divided by the square of height in metres). Following the WHO criteria, 'overweight' was defined as $25-29.9 \mathrm{~kg} \mathrm{~m}^{-2}$ and 'obese' as $30 \mathrm{~kg} \mathrm{~m}^{-2}$ or more (WHO, 1995). We excluded recruits who reported that they had been previously diagnosed with cancer, defined as in situ breast carcinoma or any malignancy except non-melanoma skin cancer (ICD-10 D05 or any ICD-10 C code except C44). For the remaining women, observation extended from the date of recruitment to the date of the earliest of four possible outcomes: cancer diagnosis, emigration, death, or end of follow-up. Follow-up ended on 31 December 2008 for Scotland and the North West (Merseyside and Cheshire) cancer registry region, and 31 December 2009 elsewhere.

Adjusted relative risks (RRs) of haematological cancer were estimated by Cox regression, using attained age as the underlying time variable, with stratification by cancer registry region of residence at recruitment. Exposure categories were derived from information reported on the recruitment questionnaire: body mass index, height, socioeconomic status (quintiles of the Townsend deprivation index of residence at recruitment), alcohol consumption (none, $0.5-<3,3-<7$, and $\geqslant 7$ units per week), and smoking status (never, past, and current). Body mass index and height were treated in turn as the main explanatory variable, adjusting for all the other factors. Trends were assessed by allocating a score to each category of the explanatory variable (the mean measurement among sampled participants within the

Table 1. Number of women diagnosed with haematological malignancy during follow-up: ICD-O-3 classification (Million Women Study, United Kingdom 1996-2009)

\begin{tabular}{|c|c|c|c|}
\hline Subgroup & Subtype & ICD-O-3 morphology (all with behaviour code 3 , malignant) & Cases \\
\hline \multicolumn{4}{|l|}{ Lymphoid malignancies } \\
\hline Hodgkin lymphoma & Hodgkin lymphoma & $9650-9667$ & 287 \\
\hline Mature B cell & $\begin{array}{l}\text { Diffuse large B cell } \\
\text { Follicular lymphoma } \\
\text { Plasma cell neoplasms } \\
\text { CLL/SLL } \\
\text { Other }\end{array}$ & $\begin{array}{l}9678-9684 \\
9690-9698 \\
9731-9734 \\
9670,9823 \\
9671,9673,9687,9689,9699,9760-9762,9764,9826,9833,9940\end{array}$ & $\begin{array}{r}1152 \\
1027 \\
1518 \\
920 \\
476\end{array}$ \\
\hline Mature $T$ cell & Mature T cell & 9700-9719, 9827, 9831, 9834, 9948 & 197 \\
\hline Other/unspecified & $\begin{array}{l}\text { Precursor cell } \\
\text { Unspecified }\end{array}$ & $\begin{array}{l}9727-9729,9835-9837 \\
9590,9591,9596,9675,9820,9832\end{array}$ & $\begin{array}{r}74 \\
1396\end{array}$ \\
\hline \multicolumn{4}{|l|}{ Myeloid malignancies } \\
\hline $\begin{array}{l}\text { Acute myeloid leukaemia } \\
\text { Myeloproliferative/dysplastic } \\
\text { Unspecified }\end{array}$ & $\begin{array}{l}\text { Acute myeloid leukaemia } \\
\text { Myeloproliferative/dysplastic } \\
\text { Unspecified }\end{array}$ & $\begin{array}{l}\text { 9840, 9861, 9866-9874, 9891-9910, 9930, 9931, 9984 } \\
9740-9742,9863,9875,9876,9945,9946,9950,9960-9964,9980-9983,9985-9989 \\
9860\end{array}$ & $\begin{array}{r}617 \\
1430 \\
25\end{array}$ \\
\hline \multicolumn{4}{|l|}{ Unspecified lineage } \\
\hline Unspecified & Unspecified & $9800,9801,9805$ & 43 \\
\hline Total & & & 9162 \\
\hline 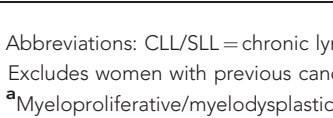 & $\begin{array}{l}\text { ocytic leukaemia/small lymphocytic } \\
\text { Includes women with missing data }\end{array}$ & $\begin{array}{l}\text { ymphoma; ICD-O-3= International Classification of Diseases for Oncology 3rd edition. } \\
\text { n body mass index and height. Excludes histiocytic/dendritic neoplasms (9750-9758). } \\
\text { aemia. }\end{array}$ & \\
\hline
\end{tabular}


category), and fitting log-linear models to the change in hazard ratio per unit increase in score. Heterogeneity of trends between diagnostic groups was assessed by a $\chi^{2}$ contrast test (Smith-Warner et al, 2006). The proportional hazards assumption was examined using Schoenfeld residuals, and found acceptable. To investigate the possibility that associations might be influenced by changes in body size caused by subclinical disease (reverse causation), all analyses were repeated excluding the first 3 years of follow-up. All statistical tests were two-sided and used the 5\% significance level.

\section{RESULTS}

Descriptive statistics. Of the 1364156 women potentially eligible for this analysis, we excluded 45035 who reported prior cancer at recruitment. Of the remaining women, we excluded 21499 with missing height data, leaving 1297622 for the height analyses, and a further 47725 with missing weight data, leaving 1249897 for the body mass index analyses. At recruitment, 95\% were aged 50-65 years. The mean age at recruitment was 56.6 years, and the mean follow-up period was 10.3 years. Some characteristics of the cohort are summarised in Table 2 for each category of body mass index and height. Women with higher body mass index tended to be of lower socioeconomic status, and were less likely to be current smokers or frequent alcohol drinkers; taller women tended to be of higher socioeconomic status, were slightly younger on average, and were less likely to be current smokers but more likely to be frequent alcohol drinkers. Other characteristics have been reported elsewhere (Reeves et al, 2007; Green et al, 2011).

Before exclusions for missing height and weight data, the number of haematological cancers diagnosed during follow-up was 9162 according to the ICD-O-3 classification, or 7929 in ICD-10; these numbers differ because many cases included in the ICD-O-3 myeloproliferative/myelodysplastic group are not treated as malignant in ICD-10 (Kroll et al, 2012). Table 1 reports numbers of cases by ICD-O-3 subtype: $77 \%$ were lymphoid and $23 \%$ were myeloid. Among lymphoid malignancies, the most frequent subgroup was mature B cell (72\%); the 'other/unspecified' category $(21 \%)$ included a small proportion of precursor-cell cases, but otherwise contained unspecified lymphoid cases. Among mature B-cell malignancies, the most frequent subtypes were plasma cell neoplasms (30\%), diffuse large B-cell lymphoma (23\%), follicular lymphoma (20\%), and CLL/SLL (18\%); the 'other' category (9\%) included marginal zone and mantle cell lymphomas, and immunoproliferative diseases. Among myeloid malignancies, the most frequent subgroups were myeloproliferative/myelodysplastic neoplasms (69\%) and acute myeloid leukaemia (30\%). Overall, the proportion of cases assigned to unspecified subtypes was $16 \%$.

Relative risks for categories of body mass index and height are given in Tables 3 and 4 . Estimated trends in risk per $10 \mathrm{~kg} \mathrm{~m}^{-2}$ increase in body mass index, and per $10 \mathrm{~cm}$ increase in height, are shown in Figure 1.

Body mass index. Classifying by ICD-O-3, the risk of haematological malignancy among obese women (over $30 \mathrm{~kg} \mathrm{~m}^{-2}$ ) was 1.25 (95\% confidence interval 1.18-1.33) relative to the reference group (under $25 \mathrm{~kg} \mathrm{~m}^{-2}$ ). Overall, the relative risk for an increase of $10 \mathrm{~kg} \mathrm{~m}^{-2}$ (trend) was $1.24(1.18-1.31) ; P_{\text {trend }}<0.001$. There were increasing trends for both lymphoid $\left(1.20(1.13-1.28)\right.$; $\left.P_{\text {trend }}<0.001\right)$ and myeloid $\left(1.37(1.22-1.53) ; P_{\text {trend }}<0.001\right)$ malignancies, and a test for heterogeneity between the two groups was not statistically significant $\left(P_{\text {het }}=0.06\right)$. There was no significant heterogeneity between trends for lymphoid subgroups $\left(P_{\text {het }}=0.1\right)$; there were significant trends for Hodgkin lymphoma (1.64 (1.21-2.21); $\left.P_{\text {trend }}=0.001\right)$ and mature B-cell neoplasms (1.16 (1.08-1.25); $\left.P_{\text {trend }}<0.001\right)$. Similarly, there was no significant heterogeneity between trends for mature B-cell subtypes $\left(P_{\text {het }}=0.07\right)$; there were significant trends for diffuse large B-cell lymphoma (1.36 (1.17-1.58); $\left.P_{\text {trend }}<0.001\right)$ and plasma cell neoplasms (1.21 (1.06-1.39); $\left.P_{\text {trend }}=0.005\right)$. Among the myeloid subgroups, there were significant increases for both acute myeloid leukaemia (1.47 (1.19-1.81); $\left.P_{\text {trend }}<0.001\right)$ and myeloproliferative/myelodysplastic neoplasms (1.32 (1.15-1.52); $\left.P_{\text {trend }}<0.001\right)$, with no significant heterogeneity $\left(P_{\text {het }}=0.4\right)$.

Table 2. Characteristics of the study population, by categories of self-reported body mass index and height (Million Women Study, United Kingdom 1996-2009)

\begin{tabular}{|c|c|c|c|c|c|c|}
\hline & \multicolumn{3}{|c|}{ Body-mass index $\left(\mathrm{kg} \mathrm{m}^{-2}\right)$} & \multicolumn{3}{|c|}{ Height $(\mathrm{cm})$} \\
\hline Self-reported at recruitment & $<25$ & $25-29$ & $30+$ & $<160$ & $160-164$ & $165+$ \\
\hline Number of women & 578091 & 447348 & 224458 & 430424 & 388678 & 478520 \\
\hline \multicolumn{7}{|l|}{ Characteristics at recruitment } \\
\hline $\begin{array}{l}\text { Drinkers }{ }^{\mathrm{a}}(\%) \\
\text { Current smokers (\%) } \\
\text { Lower socioeconomic status }^{\mathrm{b}}(\%) \\
\text { Age (years): mean (s.d.) }\end{array}$ & $\begin{array}{c}80 \\
23 \\
29 \\
56.4(4.9)\end{array}$ & $\begin{array}{c}77 \\
19 \\
34 \\
56.9(4.9)\end{array}$ & $\begin{array}{c}67 \\
17 \\
42 \\
56.7(4.8)\end{array}$ & $\begin{array}{c}73 \\
23 \\
38 \\
56.7(4.9)\end{array}$ & $\begin{array}{c}77 \\
20 \\
32 \\
56.7(4.9)\end{array}$ & $\begin{array}{c}79 \\
19 \\
30 \\
56.5(4.8)\end{array}$ \\
\hline \multicolumn{7}{|l|}{ Follow-up } \\
\hline $\begin{array}{l}\text { Woman-years observed (1000s) } \\
\text { Number of incident cases: ICDO-3 } \\
\text { Number of incident cases: ICD-10 }\end{array}$ & $\begin{array}{l}5991.2 \\
3676 \\
3191\end{array}$ & $\begin{array}{l}4610.8 \\
3213 \\
2780\end{array}$ & $\begin{array}{c}2285.5 \\
1757 \\
1522\end{array}$ & $\begin{array}{l}4422.8 \\
2710 \\
2318\end{array}$ & $\begin{array}{l}4008.1 \\
2674 \\
2323\end{array}$ & $\begin{array}{c}4942.1 \\
3597 \\
3143\end{array}$ \\
\hline \multicolumn{7}{|c|}{ Measurements of sampled women } \\
\hline $\begin{array}{l}\text { Mean (s.d.) } \\
\text { Sample size }\end{array}$ & $\begin{array}{c}23.9(2.7) \\
2006\end{array}$ & $\begin{array}{c}28.6(2.9) \\
1227\end{array}$ & $\begin{array}{c}34.5(4.7) \\
445\end{array}$ & $\begin{array}{c}154.7(3.8) \\
1083\end{array}$ & $\begin{array}{c}160.4(2.9) \\
1135\end{array}$ & $\begin{array}{c}167.0(4.2) \\
1543\end{array}$ \\
\hline $\begin{array}{l}\text { Abbreviations: ICDO- } 3=\text { International } \\
a_{2} \geqslant 0.5 \text { drinks per week, in units equivale } \\
b_{\text {Within-study tertile of the } 1991 \text { Townse }}\end{array}$ & for Oncolog & on; ICD-10 & onal Classif & Diseases 10t & . & \\
\hline
\end{tabular}


Table 3. Association of body mass index with risk of haematological malignancies (Million Women Study, United Kingdom 1996-2009)

\begin{tabular}{|c|c|c|c|c|c|c|c|c|c|c|}
\hline \multirow[b]{2}{*}{ Body mass index $\left(\mathrm{kg} \mathrm{m}^{-2}\right)^{a}$} & \multicolumn{2}{|c|}{$<25$} & \multicolumn{3}{|c|}{$25-29$} & \multicolumn{3}{|c|}{$30+$} & \multicolumn{2}{|c|}{ All women ${ }^{b}$} \\
\hline & Cases & Ref. & Cases & RR & $95 \% \mathrm{Cl}$ & Cases & RR & $95 \% \mathrm{Cl}$ & Cases & $\boldsymbol{P}_{\text {trend }}$ \\
\hline \multicolumn{11}{|c|}{ All haematological malignancies } \\
\hline ICD-O-3 classification & 3676 & 1.00 & 3213 & 1.12 & $1.07,1.17$ & 1757 & 1.25 & $1.18,1.33$ & 8646 & $<0.001$ \\
\hline ICD-10 classification & 3191 & 1.00 & 2780 & 1.11 & $1.06,1.17$ & 1522 & 1.25 & $1.17,1.33$ & 7493 & $<0.001$ \\
\hline \multicolumn{11}{|c|}{ Subgroups of ICD-O-3 classification } \\
\hline \multicolumn{11}{|c|}{ ICD-O-3 haematological malignancies ${ }^{c}$} \\
\hline Lymphoid & 2857 & 1.00 & 2464 & 1.10 & $1.04,1.16$ & 1332 & 1.21 & $1.14,1.30$ & 6653 & $<0.001$ \\
\hline Myeloid & 801 & 1.00 & 737 & 1.18 & $1.07,1.31$ & 414 & 1.38 & $1.22,1.56$ & 1952 & $<0.001$ \\
\hline \multicolumn{11}{|l|}{ ICD-O-3 lymphoid malignancies } \\
\hline Hodgkin lymphoma & 95 & 1.00 & 110 & 1.49 & $1.13,1.97$ & 62 & 1.66 & $1.20,2.31$ & 267 & 0.001 \\
\hline Mature B cell & 2087 & 1.00 & 1770 & 1.07 & $1.01,1.14$ & 945 & 1.17 & $1.08,1.27$ & 4802 & $<0.001$ \\
\hline Mature T cell & 85 & 1.00 & 62 & 0.95 & $0.69,1.33$ & 39 & 1.28 & $0.87,1.88$ & 186 & 0.3 \\
\hline Other/unspecified lymphoid & 590 & 1.00 & 522 & 1.15 & $1.02,1.30$ & 286 & 1.28 & $1.11,1.48$ & 1398 & $<0.001$ \\
\hline \multicolumn{11}{|c|}{ ICD-O-3 subtypes of mature B-cell malignancy } \\
\hline Diffuse large B-cell lymphoma & 439 & 1.00 & 413 & 1.18 & $1.03,1.35$ & 236 & 1.37 & $1.17,1.62$ & 1088 & $<0.001$ \\
\hline Follicular lymphoma & 459 & 1.00 & 326 & 0.92 & $0.80,1.06$ & 180 & 1.04 & $0.87,1.24$ & 965 & 0.9 \\
\hline Plasma cell neoplasms & 600 & 1.00 & 538 & 1.12 & $1.00,1.26$ & 289 & 1.22 & $1.06,1.41$ & 1427 & 0.005 \\
\hline CLL/SLL & 386 & 1.00 & 323 & 1.07 & $0.92,1.24$ & 164 & 1.13 & $0.93,1.36$ & 873 & 0.2 \\
\hline Other mature B cell & 203 & 1.00 & 170 & 1.05 & $0.86,1.29$ & 76 & 0.97 & $0.74,1.27$ & 449 & 0.9 \\
\hline \multicolumn{11}{|l|}{ ICD-O-3 myeloid malignancies ${ }^{d}$} \\
\hline Acute myeloid leukaemia & 232 & 1.00 & 212 & 1.17 & $0.97,1.41$ & 134 & 1.51 & $1.21,1.87$ & 578 & $<0.001$ \\
\hline Myeloproliferative/dysplastic & 562 & 1.00 & 512 & 1.17 & $1.04,1.32$ & 277 & 1.33 & $1.15,1.55$ & 1351 & $<0.001$ \\
\hline \multicolumn{11}{|c|}{ Subgroups of ICD-10 classification } \\
\hline \multicolumn{11}{|c|}{ ICD-10 haematological malignancies } \\
\hline Hodgkin lymphoma & 95 & 1.00 & 110 & 1.49 & $1.13,1.97$ & 62 & 1.66 & $1.20,2.31$ & 267 & 0.001 \\
\hline $\mathrm{NHL}$ & 1744 & 1.00 & 1459 & 1.07 & $1.00,1.15$ & 815 & 1.22 & $1.12,1.33$ & 4018 & $<0.001$ \\
\hline Myeloma & 643 & 1.00 & 563 & 1.09 & $0.98,1.23$ & 297 & 1.17 & $1.02,1.35$ & 1503 & 0.02 \\
\hline Leukaemia & 709 & 1.00 & 648 & 1.18 & $1.06,1.31$ & 348 & 1.31 & $1.15,1.50$ & 1705 & $<0.001$ \\
\hline \multicolumn{11}{|c|}{ 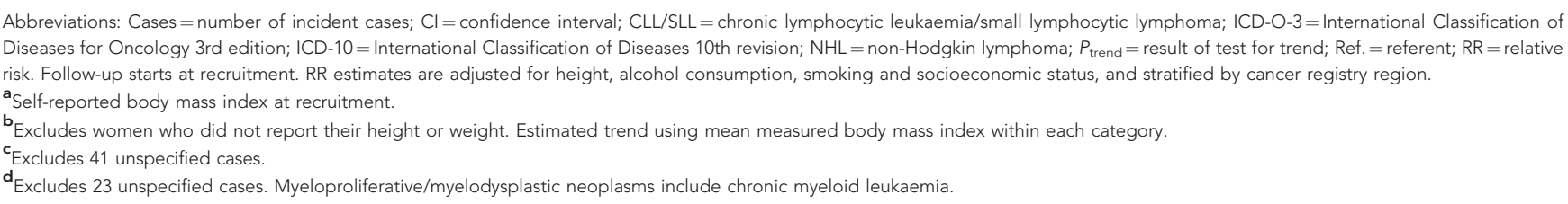 } \\
\hline
\end{tabular}

Using the ICD-10 classification, there were increases for all groups: Hodgkin lymphoma (1.64 (1.21-2.21); $\left.P_{\text {trend }}=0.001\right)$, NHL (1.21 (1.11-1.31); $\left.P_{\text {trend }}<0.001\right)$, myeloma (1.17 (1.02-1.33); $\left.P_{\text {trend }}=0.02\right)$, and leukaemia $\left(1.31(1.16-1.48) ; P_{\text {trend }}<0.001\right)$. The test for heterogeneity between trends was not significant $\left(P_{\text {het }}=0.2\right)$.

Excluding the first 3 years of follow-up did not appreciably change the trend estimates (see Table 5); the association between adiposity and myeloma using ICD-10 became non-significant $\left(P_{\text {trend }}=0.08\right)$.

Height. Using the ICD-O-3 classification, the risk of haematological malignancy for taller women (over $165 \mathrm{~cm}$ ) relative to the reference group (under $160 \mathrm{~cm}$ ) was $1.24(1.18-1.31$ ), and the overall trend per $10 \mathrm{~cm}$ increase in height was 1.19 (1.15-1.24); $P_{\text {trend }}<0.001$. There were increasing trends for both lymphoid (1.21 (1.16-1.27); $\left.P_{\text {trend }}<0.001\right)$ and myeloid (1.11 (1.02-1.21); $\left.P_{\text {trend }}=0.02\right)$ malignancies, and the test for heterogeneity between the trends for these two groups was not significant $\left(P_{\text {het }}=0.07\right)$. There was no significant heterogeneity among trends for the lymphoid malignancies: there were significant increases for mature
B-cell neoplasms (1.21 (1.15-1.28); $\left.P_{\text {trend }}<0.001\right)$ and mature T-cell neoplasms (1.36 (1.03-1.79); $\left.P_{\text {trend }}=0.03\right)$, with a borderline significant increase for Hodgkin lymphoma (1.25 (1.00-1.57); $\left.P_{\text {trend }}=0.05\right)$. There were significant increases for all malignant B-cell subtypes, with no significant heterogeneity: diffuse large B-cell lymphoma (1.28 (1.14-1.43); $\left.\quad P_{\text {trend }}<0.001\right)$, follicular lymphoma $\left(1.28(1.13-1.44) ; P_{\text {trend }}<0.001\right)$, plasma cell neoplasms (1.12 (1.01-1.24); $\left.P_{\text {trend }}=0.03\right)$, and CLL/SLL (1.23 (1.08-1.40); $\left.P_{\text {trend }}=0.001\right)$. There was no statistically significant heterogeneity among the myeloid subgroups, with a significant increase for acute myeloid leukaemia $\left(1.22(1.04-1.42) ; P_{\text {trend }}=0.01\right)$ but not for myeloproliferative/myelodysplastic neoplasms.

Using the ICD-10 classification, there were increases for NHL (1.23 (1.16-1.31); $\left.P_{\text {trend }}<0.001\right)$, myeloma (1.12 (1.01-1.23); $\left.P_{\text {trend }}=0.03\right)$, and leukaemia $\left(1.26(1.15-1.38) ; P_{\text {trend }}<0.001\right)$, and a borderline significant increase for Hodgkin lymphoma (1.25 (1.001.57); $P=0.05)$. The test for heterogeneity of trends was not significant $\left(P_{\text {het }}=0.3\right)$.

When the first 3 years of follow-up were excluded, the trend estimates did not appreciably change (see Table 5). The test for 
Table 4. Association of height with risk of haematological malignancies (Million Women Study, United Kingdom 1996-2009)

\begin{tabular}{|c|c|c|c|c|c|c|c|c|c|c|}
\hline \multirow[b]{2}{*}{ Height $(\mathrm{cm})^{a}$} & \multicolumn{2}{|c|}{$<160$} & \multicolumn{3}{|c|}{$160-164$} & \multicolumn{3}{|c|}{$165+$} & \multicolumn{2}{|c|}{ All women ${ }^{b}$} \\
\hline & Cases & Ref. & Cases & RR & $95 \% \mathrm{Cl}$ & Cases & RR & $95 \% \mathrm{Cl}$ & Cases & $\boldsymbol{P}_{\text {trend }}$ \\
\hline \multicolumn{11}{|c|}{ All haematological malignancies } \\
\hline ICD-O-3 classification & 2710 & 1.00 & 2674 & 1.11 & $1.05,1.17$ & 3597 & 1.24 & $1.18,1.31$ & 8981 & $<0.001$ \\
\hline ICD-10 classification & 2318 & 1.00 & 2323 & 1.13 & $1.07,1.20$ & 3143 & 1.28 & $1.21,1.35$ & 7784 & $<0.001$ \\
\hline \multicolumn{11}{|c|}{ Subgroups of ICD-O-3 classification } \\
\hline \multicolumn{11}{|c|}{ ICD-O-3 haematological malignancies ${ }^{c}$} \\
\hline Lymphoid & 2050 & 1.00 & 2066 & 1.13 & $1.07,1.21$ & 2788 & 1.27 & $1.20,1.35$ & 6904 & $<0.001$ \\
\hline Myeloid & 651 & 1.00 & 595 & 1.03 & $0.92,1.15$ & 788 & 1.13 & $1.02,1.26$ & 2034 & 0.02 \\
\hline \multicolumn{11}{|l|}{ ICD-O-3 lymphoid malignancies } \\
\hline Hodgkin lymphoma & 90 & 1.00 & 79 & 1.06 & $0.78,1.44$ & 113 & 1.31 & $0.99,1.73$ & 282 & 0.05 \\
\hline Mature B cell & 1491 & 1.00 & 1478 & 1.11 & $1.03,1.20$ & 2017 & 1.26 & $1.18,1.35$ & 4986 & $<0.001$ \\
\hline Mature T cell & 44 & 1.00 & 73 & 1.87 & $1.29,2.72$ & 75 & 1.60 & $1.09,2.33$ & 192 & 0.03 \\
\hline Other/unspecified lymphoid & 425 & 1.00 & 436 & 1.15 & $1.01,1.32$ & 583 & 1.27 & $1.12,1.44$ & 1444 & $<0.001$ \\
\hline \multicolumn{11}{|c|}{ ICD-O-3 subtypes of mature B-cell malignancy } \\
\hline Diffuse large B-cell lymphoma & 327 & 1.00 & 344 & 1.20 & $1.03,1.40$ & 460 & 1.36 & $1.18,1.58$ & 1131 & $<0.001$ \\
\hline Follicular lymphoma & 282 & 1.00 & 303 & 1.19 & $1.01,1.40$ & 420 & 1.36 & $1.17,1.58$ & 1005 & $<0.001$ \\
\hline Plasma cell neoplasms & 470 & 1.00 & 433 & 1.03 & $0.91,1.18$ & 576 & 1.15 & $1.01,1.30$ & 1479 & 0.03 \\
\hline CLL/SLL & 269 & 1.00 & 259 & 1.07 & $0.90,1.27$ & 375 & 1.29 & $1.10,1.51$ & 903 & 0.001 \\
\hline Other mature B cell & 143 & 1.00 & 139 & 1.08 & $0.85,1.36$ & 186 & 1.19 & $0.96,1.49$ & 468 & 0.1 \\
\hline \multicolumn{11}{|l|}{ ICD-O-3 myeloid malignancies ${ }^{d}$} \\
\hline Acute myeloid leukaemia & 191 & 1.00 & 165 & 0.99 & $0.80,1.22$ & 249 & 1.26 & $1.04,1.52$ & 605 & 0.01 \\
\hline Myeloproliferative/dysplastic & 450 & 1.00 & 423 & 1.05 & $0.92,1.20$ & 531 & 1.09 & $0.96,1.24$ & 1404 & 0.2 \\
\hline \multicolumn{11}{|c|}{ Subgroups of ICD-10 classification } \\
\hline \multicolumn{11}{|c|}{ ICD-10 haematological malignancies } \\
\hline Hodgkin lymphoma & 90 & 1.00 & 79 & 1.06 & $0.78,1.44$ & 113 & 1.31 & $0.99,1.73$ & 282 & 0.05 \\
\hline $\mathrm{NHL}$ & 1206 & 1.00 & 1273 & 1.19 & $1.10,1.29$ & 1686 & 1.31 & $1.21,1.41$ & 4165 & $<0.001$ \\
\hline Myeloma & 495 & 1.00 & 455 & 1.03 & $0.90,1.17$ & 608 & 1.14 & $1.01,1.29$ & 1558 & 0.03 \\
\hline Leukaemia & 527 & 1.00 & 516 & 1.11 & $0.98,1.25$ & 736 & 1.32 & $1.18,1.48$ & 1779 & $<0.001$ \\
\hline \multicolumn{11}{|c|}{ 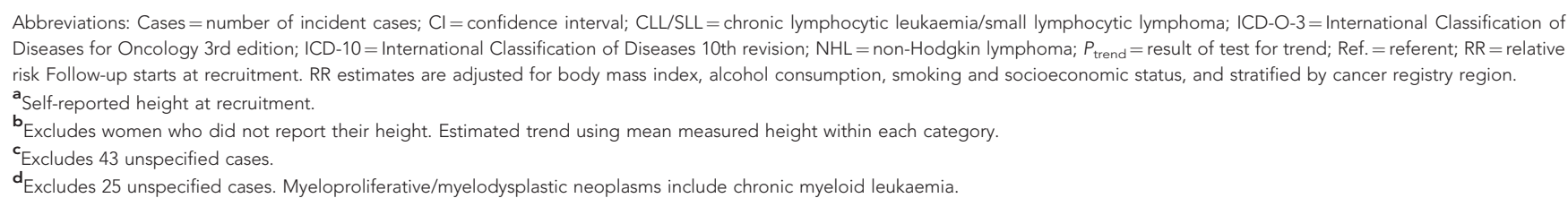 } \\
\hline
\end{tabular}

heterogeneity between the lymphoid and myeloid groups moved from marginally non-significant $\left(P_{\text {het }}=0.07\right)$ to marginally significant $\left(P_{\text {het }}=0.03\right)$, the trend for 'other mature B-cell malignancies' became marginally significant $\left(P_{\text {trend }}=0.04\right)$, and the trends for myeloid and mature T-cell malignancies and acute myeloid leukaemia became non-significant.

\section{DISCUSSION}

In this cohort of middle-aged women, greater adiposity and height were associated with increased risk of haematological cancer. For both measures, there were statistically significant associations with most of the disease subtypes analysed, using a detailed classification based on ICD-O-3. The overall increases in risk were not very large: for example, $25 \%$ for obese women compared with normal/ underweight, and $24 \%$ for women over $165 \mathrm{~cm}$ compared with under $160 \mathrm{~cm}$. We found no statistically significant heterogeneity between trends for subtypes within diagnostic groups, implying that chance cannot be ruled out as an explanation of the apparent differences in trend. However, the associations are very unlikely to have occurred by chance, as 16 of the 28 trend tests were significant with $P \leqslant 0.001$. Reverse causation is improbable, because the trend estimates did not appreciably change when the first 3 years of follow-up were excluded (although some trends became non-significant, presumably due to smaller numbers of cases). Consistent results were obtained using a broader ICD-10 classification.

Body mass index. Our findings are consistent with meta-analyses of previous prospective studies using disease categories compatible with our ICD-O-3 classification, which reported positive associations with body mass index for diffuse large B-cell lymphoma, acute myeloid leukaemia, and chronic myeloid leukaemia (a type of myeloproliferative neoplasm), but not for follicular lymphoma or CLL/SLL (Larsson and Wolk, 2008, 2011), and with comparable case-control studies (Cerhan et al, 2005; Chang et al, 2005; Kasim 


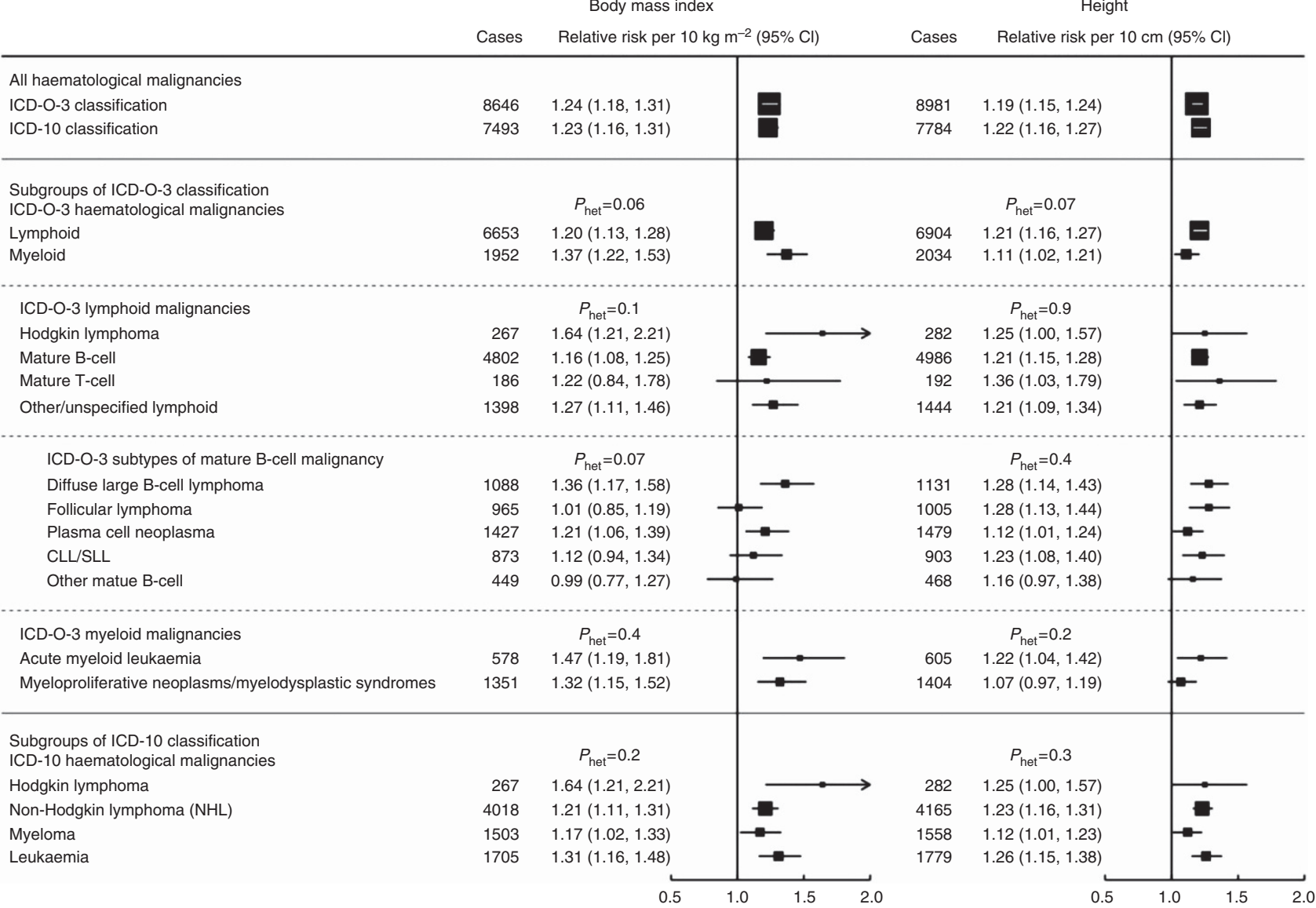

Figure 1. Associations of body mass index and height with risk of haematological malignancies. Million Women Study, United Kingdom 1996-2009. Follow-up starts at recruitment. Relative risks are adjusted for alcohol intake, smoking, and socioeconomic status (and for body mass index and height where not the factor of interest) and stratified by cancer registry region. ICD-O-3, International Classification of Diseases for Oncology 3rd edition; ICD-10, International Classification of Diseases 10th revision; CLL/SLL, chronic lymphocytic leukaemia/ small lymphocytic lymphoma; Cases, number of incident cases; $\mathrm{Cl}$, confidence interval; $P_{\text {het, }}$ result of test for heterogeneity of trends within groups. Myeloproliferative neoplasms/myelodysplastic syndromes include chronic myeloid leukaemia.

et al, 2005; Pan et al, 2005; Willett et al, 2008). A small meta-analysis of five prospective studies of Hodgkin lymphoma reported an increase in the relative risk of disease for obese but not for overweight individuals (Larsson and Wolk, 2011); in contrast, we found increased risk in both overweight and obese women, probably reflecting greater statistical power. Our results are also consistent with the few previous studies of diagnostic groups not included in the meta-analyses: individual cohort studies reported positive associations with plasma cell neoplasms (Engeland et al, 2007; Troy et al, 2010) and myelodysplastic syndromes (Ma et al, 2009), but not mature T-cell malignancies (Lim et al, 2007). Using the ICD-10 classification, our results for NHL, myeloma, and leukaemia are consistent with an earlier report from the same cohort with only 5.4 years of follow-up (Reeves et al, 2007), and with meta-analyses that included it (Renehan et al, 2008; Wallin and Larsson, 2011).

Although heterogeneity tests were non-significant, the association with adiposity appeared to be much weaker for follicular lymphoma than for the more aggressive subtypes such as Hodgkin and diffuse large B-cell lymphoma. Conceivably, this might reflect differential delay in diagnosis associated with obesity: earlystage follicular lymphoma often has no obvious symptoms, and obesity would make enlarged peripheral lymph nodes more difficult to detect.

Height. A recent meta-analysis of prospective studies reported a positive association of greater height with all-cancer risk in both sexes, which remained after exclusion of the Million Women Study (Green et al, 2011). To our knowledge, there has been no meta-analysis of the association for haematological cancer specifically.

Using ICD-O-3, we found increased risks of both lymphoid and myeloid cancer, and of many subtypes. Positive associations have been previously reported for lymphoproliferative and myeloproliferative malignancies both separately and combined (Engeland et al, 2007), and for Hodgkin lymphoma (Engeland et al, 2007), diffuse large B-cell lymphoma (Troy et al, 2010), follicular lymphoma (Cerhan et al, 2005; Britton et al, 2008), plasma cell neoplasms (Engeland et al, 2007), CLL/SLL (Lu et al, 2009; Troy et al, 2010), and acute myeloid leukaemia (Engeland et al, 2007). One study analysed mature T-cell disease but found no significant association (Lim et al, 2007). Except for Hodgkin lymphoma (which was on the borderline of significance), we found statistically significant associations for all these subtypes.

Using ICD-10, our results for NHL, myeloma and leukaemia are consistent with a report from this cohort after 9 years of follow-up, although the association was then marginally nonsignificant for multiple myeloma (Green et al, 2011). Perhaps reflecting lower statistical power, previous studies using comparable classifications reported no association for NHL (Cerhan et al, 2002), and only marginally significant association for leukaemia (Ross et al, 2004). 
Table 5. Associations of body mass index and height with risk of haematological malignancies, excluding the first 3 years of follow-up (Million Women Study, United Kingdom 1996-2009)

\begin{tabular}{|c|c|c|c|c|c|c|c|c|}
\hline & \multicolumn{4}{|c|}{ Body mass index (per $10 \mathrm{~kg} \mathrm{~m}^{-2}$ ) } & \multicolumn{4}{|c|}{ Height (per $10 \mathrm{~cm}$ ) } \\
\hline & Cases & RR & $95 \% \mathrm{Cl}$ & $\boldsymbol{P}_{\text {trend }}$ & Cases & RR & $95 \% \mathrm{Cl}$ & $P_{\text {trend }}$ \\
\hline \multicolumn{9}{|l|}{ All haematological malignancies } \\
\hline $\begin{array}{l}\text { ICD-O-3 classification } \\
\text { ICD-10 classification }\end{array}$ & $\begin{array}{l}6836 \\
5913\end{array}$ & $\begin{array}{l}1.25 \\
1.24\end{array}$ & $\begin{array}{l}1.17,1.33 \\
1.16,1.33\end{array}$ & $\begin{array}{l}<0.001 \\
<0.001\end{array}$ & $\begin{array}{l}7104 \\
6149\end{array}$ & $\begin{array}{l}1.18 \\
1.21\end{array}$ & $\begin{array}{l}1.13,1.24 \\
1.15,1.27\end{array}$ & $\begin{array}{l}<0.001 \\
<0.001\end{array}$ \\
\hline \multicolumn{9}{|l|}{ Subgroups of ICD-O-3 classification } \\
\hline ICD-O-3 haematological malignancies ${ }^{a}$ & \multicolumn{4}{|c|}{$P_{\text {het }}=0.5$} & \multicolumn{4}{|c|}{$P_{\text {het }}=0.03$} \\
\hline $\begin{array}{l}\text { Lymphoid } \\
\text { Myeloid }\end{array}$ & $\begin{array}{l}5267 \\
1534\end{array}$ & $\begin{array}{l}1.23 \\
1.29\end{array}$ & $\begin{array}{l}1.15,1.32 \\
1.13,1.47\end{array}$ & $\begin{array}{l}<0.001 \\
<0.001\end{array}$ & $\begin{array}{l}5474 \\
1595\end{array}$ & $\begin{array}{l}1.21 \\
1.07\end{array}$ & $\begin{array}{l}1.15,1.27 \\
0.97,1.18\end{array}$ & $\begin{array}{l}<0.001 \\
0.2\end{array}$ \\
\hline ICD-O-3 lymphoid malignancies & \multicolumn{4}{|c|}{$P_{\text {het }}=0.06$} & \multicolumn{4}{|c|}{$P_{\text {het }}=0.9$} \\
\hline $\begin{array}{l}\text { Hodgkin lymphoma } \\
\text { Mature B cell } \\
\text { Mature T cell } \\
\text { Other/unspecified lymphoid }\end{array}$ & $\begin{array}{r}201 \\
3934 \\
135 \\
997\end{array}$ & $\begin{array}{l}1.69 \\
1.17 \\
1.25 \\
1.41\end{array}$ & $\begin{array}{l}1.19,2.39 \\
1.08,1.27 \\
0.80,1.94 \\
1.20,1.65\end{array}$ & $\begin{array}{c}0.003 \\
<0.001 \\
0.3 \\
<0.001\end{array}$ & $\begin{array}{r}213 \\
4094 \\
140 \\
1027\end{array}$ & $\begin{array}{l}1.21 \\
1.21 \\
1.30 \\
1.18\end{array}$ & $\begin{array}{l}0.93,1.57 \\
1.14,1.29 \\
0.94,1.81 \\
1.05,1.33\end{array}$ & $\begin{array}{c}0.2 \\
<0.001 \\
0.1 \\
0.006\end{array}$ \\
\hline $\begin{array}{l}\text { ICD-O-3 subtypes of mature B-cell } \\
\text { malignancy }\end{array}$ & \multicolumn{4}{|c|}{$P_{\text {het }}=0.1$} & \multicolumn{4}{|c|}{$P_{\text {het }}=0.6$} \\
\hline $\begin{array}{l}\text { Diffuse large B-cell lymphoma } \\
\text { Follicular lymphoma } \\
\text { Plasma cell neoplasms } \\
\text { CLL/SLL } \\
\text { Other mature B cell }\end{array}$ & $\begin{array}{r}931 \\
752 \\
1166 \\
703 \\
382\end{array}$ & $\begin{array}{l}1.40 \\
1.03 \\
1.18 \\
1.11 \\
1.02\end{array}$ & $\begin{array}{l}1.19,1.65 \\
0.85,1.24 \\
1.02,1.37 \\
0.92,1.35 \\
0.78,1.34\end{array}$ & $\begin{array}{l}<0.001 \\
0.8 \\
0.03 \\
0.3 \\
0.9\end{array}$ & $\begin{array}{r}969 \\
786 \\
1211 \\
730 \\
398\end{array}$ & $\begin{array}{l}1.25 \\
1.25 \\
1.13 \\
1.26 \\
1.22\end{array}$ & $\begin{array}{l}1.11,1.42 \\
1.09,1.44 \\
1.01,1.26 \\
1.10,1.46 \\
1.01,1.48\end{array}$ & $\begin{array}{l}<0.001 \\
0.001 \\
0.04 \\
0.001 \\
0.04\end{array}$ \\
\hline ICD-O-3 myeloid malignancies ${ }^{\mathbf{b}}$ & \multicolumn{4}{|c|}{$P_{\text {het }}>0.9$} & \multicolumn{4}{|c|}{$P_{\text {het }}=0.4$} \\
\hline $\begin{array}{l}\text { Acute myeloid leukaemia } \\
\text { Myeloproliferative/myelodysplastic }\end{array}$ & $\begin{array}{r}451 \\
1068\end{array}$ & $\begin{array}{l}1.29 \\
1.29\end{array}$ & $\begin{array}{l}1.01,1.63 \\
1.10,1.50\end{array}$ & $\begin{array}{l}0.04 \\
0.002\end{array}$ & $\begin{array}{r}470 \\
1108\end{array}$ & $\begin{array}{l}1.14 \\
1.04\end{array}$ & $\begin{array}{l}0.96,1.36 \\
0.93,1.17\end{array}$ & $\begin{array}{l}0.1 \\
0.5\end{array}$ \\
\hline \multicolumn{9}{|l|}{ Subgroups of ICD-10 classification } \\
\hline ICD-10 haematological malignancies & \multicolumn{4}{|c|}{$P_{\text {het }}=0.2$} & \multicolumn{4}{|c|}{$P_{\text {het }}=0.5$} \\
\hline Hodgkin lymphoma & 201 & 1.69 & $1.19,2.39$ & 0.003 & 213 & 1.21 & $0.93,1.57$ & 0.2 \\
\hline $\mathrm{NHL}$ & 3159 & 1.26 & $1.15,1.38$ & $<0.001$ & 3277 & 1.22 & $1.14,1.31$ & $<0.001$ \\
\hline Myeloma & 1222 & 1.14 & $0.98,1.32$ & 0.08 & 1269 & 1.12 & $1.01,1.25$ & 0.03 \\
\hline Leukaemia & 1331 & 1.25 & $1.09,1.44$ & 0.002 & 1390 & 1.25 & $1.13,1.38$ & $<0.001$ \\
\hline 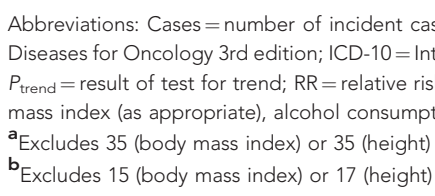 & ified case & prolife & $\begin{array}{l}=\text { chronic lymp } \\
\text { th revision; NH } \\
\text { ment. RR estin } \\
\text { us, and stratifie } \\
\text { myelodysplast }\end{array}$ & $\begin{array}{l}\text { (trend usin } \\
\text { cancer reg }\end{array}$ & $\begin{array}{l}\text { measior } \\
\text { measurer } \\
\text { gionic mye }\end{array}$ & in cate & $\begin{array}{l}3=\text { Internation } \\
\text { ogeneity of tre } \\
\text { are adjusted }\end{array}$ & $\begin{array}{l}\text { lassification } \\
\text { within grou } \\
\text { eight or bo }\end{array}$ \\
\hline
\end{tabular}

Potential mechanisms. The means by which obesity might play a role in carcinogenesis are gradually being elucidated. It is generally accepted that obesity provokes a state of chronic inflammation resulting in metabolic dysfunction and impaired immunity (Gregor and Hotamisligil, 2011). Adipocytes and infiltrating macrophages result in abnormal cytokine production, including increased synthesis of tumour necrosis factor- $\alpha$ (TNF- $\alpha$ ), which activates proinflammatory signalling pathways. Increased levels of TNF- $\alpha$ promote activation of nuclear factor $\kappa \mathrm{B}$, which can promote B-lymphocyte survival and proliferation (Ben-Neriah and Karin, 2011). Furthermore, a pooled analysis from the InterLymph consortium reported an association with a common polymorphism of TNF (TNF $-308 \mathrm{G} \rightarrow \mathrm{A}$ ) and risk of NHL, particularly diffuse large B-cell lymphoma (Rothman et al, 2006).

It is now recognised that adipose tissue is metabolically active, releasing adipokines (peptide hormones such as leptin) that help to regulate energy homeostasis. Leptin is a potent pro-inflammatory cytokine that modulates immune function, supports haematopoiesis and promotes B-cell survival (Tilg and Moschen, 2006;
Claycombe et al, 2008; Lam et al, 2010). Polymorphisms of the leptin gene and its receptor are associated with the obese phenotype, and have been shown to be associated with susceptibility to NHL (Skibola et al, 2004; Willett et al, 2005).

Less is known about potential mechanisms by which height might contribute to cancer risk. Although height is largely genetically determined, in western populations approximately $20 \%$ of variation is due to environmental factors (Silventoinen, 2003). Hormonal determinants of height may play a role in cancer risk. These include the growth hormone cascade, which is a major regulator of postnatal growth (Rosenfeld and Hwa, 2009). Insulinlike growth factor-1 levels are strongly correlated with childhood skeletal growth and there may be some relationship to levels in early life and later cancer risk (Pollak et al, 2004). Whether this process could promote the development of haematological cancers is unknown.

Strengths and weaknesses. This prospective study is based on a very large cohort of women followed for 10 years on average, 
yielding adequate power to investigate relatively rare subtypes of haematological malignancy. Reverse causation is unlikely to explain our findings, as excluding the first 3 years of follow-up did not qualitatively change the results.

Height and weight measurements were self-reported by study participants at recruitment. Some investigators have found that self-reported measurements tend to over-estimate height and under-estimate weight and BMI, particularly in women (Gorber et al, 2007). However, in our cohort, there was good agreement between self-reported and measured height and BMI for the subset of participants for whom direct measurements were available (Pearson's correlation 0.91 and 0.92 respectively) (Cairns et al, 2011). Measured height and weight data were used to score the categories in the trend analyses reported here, thus allowing for measurement error in the self-reported data.

Disease outcomes were derived from routine cancer registration data. It has been suggested that cancer registration for haematological malignancies in the United Kingdom might sometimes be incomplete or imprecise (NICE, 2003). Problems include the complexity of disease classification and coding, and the wide variety of factors involved in the diagnostic evaluation of haematological cancer, which often requires histology, immunophenotyping, and genetic studies (Smith et al, 2010). Imprecise diagnostic registration probably explains the non-trivial proportion of vaguely-defined cancers observed in our study (16\%). Conversion from ICD-O-2 to ICD-O-3 (using a standard coding table) might have introduced some misclassification: in a study from the United States, computer conversion of histology codes was found to be somewhat imprecise in comparison with ICD-O-3 coding determined directly from pathology reports, although there was a good general level of agreement (84-89\% for diffuse large B-cell lymphoma and follicular lymphoma) (Clarke et al, 2006). Finally, case ascertainment for some types of myeloproliferative/myelodysplastic disorder is likely to have been incomplete before the introduction of the 2001 WHO classification, because cancer registration was not compulsory for these diseases when their malignant nature was not fully recognised (NICE, 2003; Phekoo et al, 2006). However, there is no reason to believe that the registration problems would be differential for height or adiposity, so they are unlikely to have affected the associations reported here.

\section{CONCLUSION}

In this very large cohort of middle-aged women in the United Kingdom, greater adiposity and height were associated with modest increases in risk for many specific subtypes of haematological cancer, including both lymphoid and myeloid neoplasms. There was no statistically significant variation between trends for different subtypes within disease groups.

\section{ACKNOWLEDGEMENTS}

We thank the women who participated in the study, primary-care staff for help with validation measurements, and staff from participating NHS Breast Screening Centres. We thank Professor Eve Roman (Epidemiology and Genetics Unit, University of York) for helpful comments on the manuscript. The Million Women Study is supported by Cancer Research UK, the UK Medical Research Council, and the UK NHS breast screening programme.

\section{REFERENCES}

Armstrong ME, Spencer EA, Cairns BJ, Banks E, Pirie K, Green J, Wright FL, Reeves GK, Beral V (2011) Body mass index and physical activity in relation to the incidence of hip fracture in postmenopausal women. J Bone Miner Res 26(6): 1330-1338.

Ben-Neriah Y, Karin M (2011) Inflammation meets cancer, with NF-kappa B as the matchmaker. Nat Immunol 12(8): 715-723.

Britton JA, Khan AE, Rohrmann S, Becker N, Linseisen J, Nieters A, Kaaks R, Tjonneland A, Halkjaer J, Severinsen MT, Overvad K, Pischon T, Boeing H, Trichopoulou A, Kalapothaki V, Trichopoulos D, Mattiello A, Tagliabue G, Sacerdote C, Peeters PH, Bueno-de-Mesquita HB, Ardanaz E, Navarro C, Jakszyn P, Altzibar JM, Hallmans G, Malmer B, Berglund G, Manjer J, Allen N, Key T, Bingham S, Besson H, Ferrari P, Jenab M, Boffetta P, Vineis P, Riboli E (2008) Anthropometric characteristics and non-Hodgkin's lymphoma and multiple myeloma risk in the European Prospective Investigation into Cancer and Nutrition (EPIC). Haematologica 93(11): 1666-1677.

Cairns BJ, Liu B, Clennell S, Cooper R, Reeves GK, Beral V, Kuh D (2011) Lifetime body size and reproductive factors: comparisons of data recorded prospectively with self reports in middle age. BMC Med Res Methodol 11: 7.

Cerhan JR, Bernstein L, Severson RK, Davis S, Colt JS, Blair A, Hartge P (2005) Anthropometrics, physical activity, related medical conditions, and the risk of non-Hodgkin lymphoma. Cancer Causes Control 16(10): 1203-1214.

Cerhan JR, Janney CA, Vachon CM, Habermann TM, Kay NE, Potter JD, Sellers TA, Folsom AR (2002) Anthropometric characteristics, physical activity, and risk of non-Hodgkin's lymphoma subtypes and B-cell chronic lymphocytic leukemia: a prospective study. Am J Epidemiol 156(6): $527-535$.

Chang ET, Hjalgrim H, Smedby KE, Akerman M, Tani E, Johnsen HE, Glimelius B, Adami HO, Melbye M (2005) Body mass index and risk of malignant lymphoma in Scandinavian men and women. J Natl Cancer Inst 97(3): 210-218.

Clarke CA, Undurraga DM, Harasty PJ, Glaser SL, Morton LM, Holly EA (2006) Changes in cancer registry coding for lymphoma subtypes: reliability over time and relevance for surveillance and study. Cancer Epidemiol Biomarkers Prev 15(4): 630-638.

Claycombe K, King LE, Fraker PJ (2008) A role for leptin in sustaining lymphopoiesis and myelopoiesis. Proc Natl Acad Sci USA 105(6): 2017-2021.

Engeland A, Tretli S, Hansen S, Bjorge T (2007) Height and body mass index and risk of lymphohematopoietic malignancies in two million Norwegian men and women. Am J Epidemiol 165(1): 44-52.

Ferlay J, Shin HR, Bray F, Forman D, Mathers C, DM P (2010) Cancer Incidence and Mortality Worldwide: IARC CancerBase No. 10 [Internet]. In GLOBOCAN 2008. International Agency for Research on Cancer: Lyon, France.

Gorber SC, Tremblay M, Moher D, Gorber B (2007) A comparison of direct vs. self-report measures for assessing height, weight and body mass index: a systematic review. Obes Rev 8(4): 307-326.

Green J, Cairns BJ, Casabonne D, Wright FL, Reeves G, Beral V (2011) Height and cancer incidence in the Million Women Study: prospective cohort, and meta-analysis of prospective studies of height and total cancer risk. Lancet Oncol 12(8): 785-794.

Gregor MF, Hotamisligil GS (2011) Inflammatory mechanisms in obesity. Annu Rev Immunol 29: 415-445.

Gunnell D, Okasha M, Smith GD, Oliver SE, Sandhu J, Holly JM (2001) Height, leg length, and cancer risk: a systematic review. Epidemiol Rev 23(2): 313-342.

IARC (2008) WHO Classification of Tumours of Haematopoietic and Lymphoid Tissues. International Agency for Research on Cancer (IARC): Lyon, France.

Kasim K, Levallois P, Abdous B, Auger P, Johnson KC (2005) Lifestyle factors and the risk of adult leukemia in Canada. Cancer Causes Control 16(5): 489-500.

Kroll ME, Murphy F, Pirie K, Reeves GK, Green J, Beral V (2012) Alcohol drinking, tobacco smoking and subtypes of haematological malignancy in the UK Million Women Study. Br J Cancer 107(5): 879-887.

Lam QL, Wang S, Ko OK, Kincade PW, Lu L (2010) Leptin signaling maintains B-cell homeostasis via induction of Bcl-2 and Cyclin D1. Proc Natl Acad Sci USA 107(31): 13812-13817.

Larsson SC, Wolk A (2008) Overweight and obesity and incidence of leukemia: a meta-analysis of cohort studies. Int J Cancer 122(6): 1418-1421.

Larsson SC, Wolk A (2011) Body mass index and risk of non-Hodgkin's and Hodgkin's lymphoma: a meta-analysis of prospective studies. Eur J Cancer 47(16): 2422-2430.

Lim U, Morton LM, Subar AF, Baris D, Stolzenberg-Solomon R, Leitzmann M, Kipnis V, Mouw T, Carroll L, Schatzkin A, Hartge P (2007) 
Alcohol, smoking, and body size in relation to incident Hodgkin's and non-Hodgkin's lymphoma risk. Am J Epidemiol 166(6): 697-708.

Lu Y, Prescott J, Sullivan-Halley J, Henderson KD, Ma H, Chang ET, Clarke CA, Horn-Ross PL, Ursin G, Bernstein L (2009) Body size, recreational physical activity, and B-cell non-Hodgkin lymphoma risk among women in the California teachers study. Am J Epidemiol 170(10): 1231-1240.

Ma X, Lim U, Park Y, Mayne ST, Wang R, Hartge P, Hollenbeck AR, Schatzkin A (2009) Obesity, lifestyle factors, and risk of myelodysplastic syndromes in a large US cohort. Am J Epidemiol 169(12): 1492-1499.

NICE (2003) Improving Outcomes in Haematological Cancer: The Manual. National Institute for Clinical Excellence: London.

Pan SY, Mao Y, Ugnat AM (2005) Physical activity, obesity, energy intake, and the risk of non-Hodgkin's lymphoma: a population-based case-control study. Am J Epidemiol 162(12): 1162-1173.

Phekoo KJ, Richards MA, Moller H, Schey SA (2006) The incidence and outcome of myeloid malignancies in 2,112 adult patients in southeast England. Haematologica 91(10): 1400-1404.

Pollak MN, Schernhammer ES, Hankinson SE (2004) Insulin-like growth factors and neoplasia. Nat Rev Cancer 4(7): 505-518.

Reeves GK, Pirie K, Beral V, Green J, Spencer E, Bull D (2007) Cancer incidence and mortality in relation to body mass index in the Million Women Study: Cohort study. BMJ 335(7630): 1134-1139.

Renehan AG, Tyson M, Egger M, Heller RF, Zwahlen M (2008) Body-mass index and incidence of cancer: a systematic review and meta-analysis of prospective observational studies. Lancet 371(9612): 569-578.

Rosenfeld RG, Hwa V (2009) The growth hormone cascade and its role in mammalian growth. Horm Res 71(Suppl 2): 36-40.

Ross JA, Parker E, Blair CK, Cerhan JR, Folsom AR (2004) Body mass index and risk of leukemia in older women. Cancer Epidemiol Biomarkers Prev 13(11 Pt 1): 1810-1813.

Rothman N, Skibola CF, Wang SS, Morgan G, Lan Q, Smith MT, Spinelli JJ, Willett E, De Sanjose S, Cocco P, Berndt SI, Brennan P, Brooks-Wilson A, Wacholder S, Becker N, Hartge P, Zheng T, Roman E, Holly EA, Boffetta P, Armstrong B, Cozen W, Linet M, Bosch FX, Ennas MG, Holford TR, Gallagher RP, Rollinson S, Bracci PM, Cerhan JR, Whitby D, Moore PS, Leaderer B, Lai A, Spink C, Davis S, Bosch R, Scarpa A, Zhang Y, Severson RK, Yeager M, Chanock S, Nieters A (2006) Genetic variation in TNF and IL10 and risk of non-Hodgkin lymphoma: a report from the InterLymph Consortium. Lancet Oncol 7(1): 27-38.

Sant M, Allemani C, Tereanu C, De Angelis R, Capocaccia R, Visser O, Marcos-Gragera R, Maynadié M, Simonetti A, Lutz JM, Berrino F, Hackl M, Holub J, Maynadie M, Holleczek B, Tryggvadottir L, Comber H, Bellù F, Giacomin A, Ferretti S, Crocetti E, Serraino D, Vercelli M, Federico M, Fusco M, Michiara M, Tumino R, Mangone L, Falcini F, Iannelli A, Budroni M, Zanetti R, Piffer S, La Rosa F, Zambon P, Sowe S, England K, Langmark F, Rachtan J, Mezyk R, Zwierko M, Ondrusova M, Primic-Žakelj M, Khan S, Jundt G, Usel M, Ess SM, Bordoni A, Otter R, Coebergh JW, Siesling S, Greenberg D, Easey N, Roche M, Lawrence G, Gavin A, Brewster DH, Steward J (2010) Incidence of hematologic malignancies in Europe by morphologic subtype: Results of the HAEMACARE project. Blood 116(19): 3724-3734.

SEER (2001) ICD-O-2 to ICD-O-3 Neoplasms; available at: http:// seer.cancer.gov/tools/conversion/ICDO2-3manual.pdf, National Cancer Institute.
Silventoinen K (2003) Determinants of variation in adult body height. J Biosoc Sci 35(2): 263-285.

Skibola CF, Holly EA, Forrest MS, Hubbard A, Bracci PM, Skibola DR, Hegedus C, Smith MT (2004) Body mass index, leptin and leptin receptor polymorphisms, and non-Hodgkin lymphoma. Cancer Epidemiol Biomarkers Prev 13(5): 779-786.

Smith A, Roman E, Howell D, Jones R, Patmore R, Jack A (2010) The Haematological Malignancy Research Network (HMRN): a new information strategy for population based epidemiology and health service research. Br J Haematol 148(5): 739-753.

Smith-Warner SA, Spiegelman D, Ritz J, Albanes D, Beeson WL, Bernstein L, Berrino F, van den Brandt PA, Buring JE, Cho E, Colditz GA, Folsom AR, Freudenheim JL, Giovannucci E, Goldbohm RA, Graham S, Harnack L, Horn-Ross PL, Krogh V, Leitzmann MF, McCullough ML, Miller AB, Rodriguez C, Rohan TE, Schatzkin A, Shore R, Virtanen M, Willett WC, Wolk A, Zeleniuch-Jacquotte A, Zhang SM, Hunter DJ (2006) Methods for pooling results of epidemiologic studies: the Pooling Project of Prospective Studies of Diet and Cancer. Am J Epidemiol 163(11): 1053-1064.

Tilg H, Moschen AR (2006) Adipocytokines: mediators linking adipose tissue, inflammation and immunity. Nat Rev Immunol 6(10): 772-783.

Troy JD, Hartge P, Weissfeld JL, Oken MM, Colditz GA, Mechanic LE, Morton LM (2010) Associations between anthropometry, cigarette smoking, alcohol consumption, and non-Hodgkin lymphoma in the Prostate, Lung, Colorectal, and Ovarian Cancer Screening Trial. Am J Epidemiol 171(12): 1270-1281.

Turner JJ, Morton LM, Linet MS, Clarke CA, Kadin ME, Vajdic CM, Monnereau A, Maynadié M, Chiu BCH, Marcos-Gragera R, Costantini AS, Cerhan JR, Weisenburger DD (2010) InterLymph hierarchical classification of lymphoid neoplasms for epidemiologic research based on the WHO classification (2008): Update and future directions. Blood 116(20): e90-e98.

Wallin A, Larsson SC (2011) Body mass index and risk of multiple myeloma: a meta-analysis of prospective studies. Eur J Cancer 47(11): $1606-1615$.

WHO (1995) Physical Status: The Use and Interpretation of Anthropometry. World Health Organization Expert Committee: Geneva, Switzerland.

Willett EV, Morton LM, Hartge P, Becker N, Bernstein L, Boffetta P, Bracci P, Cerhan J, Chiu BC, Cocco P, Dal Maso L, Davis S, De Sanjose S, Smedby KE, Ennas MG, Foretova L, Holly EA, La Vecchia C, Matsuo K, Maynadie M, Melbye M, Negri E, Nieters A, Severson R, Slager SL, Spinelli JJ, Staines A, Talamini R, Vornanen M, Weisenburger DD, Roman E (2008) Non-Hodgkin lymphoma and obesity: a pooled analysis from the InterLymph Consortium. Int J Cancer 122(9): 2062-2070.

Willett EV, Skibola CF, Adamson P, Skibola DR, Morgan GJ, Smith MT, Roman E (2005) Non-Hodgkin's lymphoma, obesity and energy homeostasis polymorphisms. Br J Cancer 93(7): 811-816.

This work is published under the standard license to publish agreement. After 12 months the work will become freely available and the license terms will switch to a Creative Commons AttributionNonCommercial-Share Alike 3.0 Unported License. 